\title{
Pengembangan Usaha Mikro melalui Budidaya Ikan Lele Sangkuriang
}

\begin{abstract}
Ahmad Rifki Fathurrohman
Abstract

Abah Nasrudin adalah tokoh masyarakat yang banyak dikenal sebagai Bapak Lele Sangkuriang. Julukan ini diberikan berdasarkan apresiasi masyarakat karena kiprahnya yang telah mengembangkan serta menyebarluaskan budidaya ikan lele sangkuriang dari Bogor hingga hampir ke seluruh nusantara. Penyebaran budidaya ikan lele ini memiliki misi untuk mengangkat harkat dan martabat para pengangguran, korban PHK, serta anak putus sekolah. Dengan berbagi pengetahuan tentang pengembangan budidaya ikan lele, Abah Nasrudin berharap mampu melahirkan pengusaha-pengusaha sukses dari budidaya ikan Lele Sangkuriang, khususnya di Kecamatan Megamendung. Dengan begitu, pengangguran di Kecamatan Megamendung dapat ditanggulangi melalui peningkatan dan pengembangan usaha budidaya Ikan Lele Sangkuriang.
\end{abstract}

Key words: pemberdayaan masyarakat, usaha mikro, budidaya lele, modal sosial

\section{Pendahuluan}

Berdasarkan data BPS (Badan Pusat Statistik), tingkat pengangguran di Indonesia mengalami penurunan. Pada Februari 2013, Tingkat Penganggruran Terbuka (TPT) berjumlah sekitar 5,92\% dari jumlah penduduk Indonesia, yang awalnya mencapai $6,14 \%$ pada Agustus 2012. Artinya, terdapat pengurangan TPT sekitar 0,22\% dari jumlah sebelumnya. Meskipun begitu, jumlah tersebut masih terbilang sangat banyak mengingat jumlah warga negara Indonesia mencapai 250 juta jiwa, yang berarti TPT masih mencapai 14,8 juta jiwa.

Jumlah pengangguran di beberapa wilayah juga cenderung tinggi, misalnya di Kabupaten Bogor. Berdasarkan pernyataan Bupati Bogor, seperti dikutip dalam harian umum Pelita, pada Februari 2014, jumlah pengangguran terbuka hampir mencapai angka setengah juta, yaitu sekitar 459.000 jiwa dari total penduduk sebanyak 4.966.621 jiwa. Jika dipresentasikan, maka jumlah pengangguran terbuka di Kabupaten Bogor sekitar 9,24 \%. Bahkan secara lebih spesifik, Kecamatan Megamendung Bogor, menurut hasil Boling (Rebo Keliling) Kecamatan Megamendung tahun 2012, mencapai 94.106 jiwa. Dari jumlah tersebut, jika tingkat pengangguran dirata-ratakan pada angka 9,24\% mengacu pada TPT Kabupaten Bogor, maka jumlah TPT di Kecamatan Megamendung sekitar 8.695 jiwa dari total penduduk yang ada.

Menanggapi masalah sosial tersebut, salah satu peluang untuk menanggulanginya adalah dengan melakukan pemberdayaan dan pengembangan usaha mikro. Salah satu contohnya adalah pengembangan usaha mikro yang dilakukan oleh Abah Nasrudin dalam penanggulangan pengangguran di Kecamatan Megamendung. Abah Nasrudin adalah tokoh agrobisnis yang sudah mengembangkan dan mensosialisasikan budidaya satu jenis ikan 
lele unggul yang diberi nama Ikan Lele Sangkuriang. Kini, Abah Nasrudin sudah memiliki petani dampingan hampir di seluruh provinsi yang ada di Indonesia.

Permasalahan pengangguran di tempat kelahiran Abah Nasrudin ini membuatnya terpanggil untuk melakukan perubahan, yaitu munculnya para pengusaha Ikan Lele Sangkuriang agar perekonomian masyarakat Megamendung menjadi lebih meningkat. Dalam upayanya melakukan pemberdayaan masyarakat tersebut, Abah Nasrudin menggunakan beberapa peran strategis sebagai seorang community worker. Sehingga proses pemberdayaan melalui budidaya Ikan Lele Sangkuriang ini akan lebih terarah, terutama ketika pendampingan dilakukan langsung oleh pakarnya. Tulisan ini berupaya menelusuri strategi budidaya Ikan Lele Sangkuriang sebagai upaya pemberdayaan masyarakat.

Penelitian ini menggunakan pendekatan kualitatif, yaitu penelitian yang bertujuan untuk menjelaskan fenomena sedalam-dalamnya melalui pengumpulan data. Riset ini tidak mengutamakan besarnya jumlah informan. Jika data yang terkumpul sudah mendalam dan bisa menjelaskan fenomena yang diteliti, maka tidak perlu dicari informan lainnya. Dalam penelitian kualitatif, yang lebih ditekankan adalah persoalan kedalaman (kualitas) data bukan banyaknya (kuantitas) data (Rachmat, 2009: 56).

Berdasarkan pernyataan di atas, penulis melihat bahwa metode kualitatif sangat tepat untuk diterapkan dalam penelitian ini. Informan yang diteliti adalah Abah Nasrudin dan karyawan atau petani dampingan Abah Nasrudin. Dengan begitu, informasi yang penulis cari bisa digali menjadi lebih mendalam, serta dengan adanya informan lain sebagai pembanding, pengumpulan data maupun informasi yang penulis dapatkan menjadi lebih akurat.

\section{Konsep Pemberdayaan Masyarakat}

Menurut Edi Suharto (2005: 57), kata pemberdayaan (empowerment) berasal dari kata "power" (kekuasaan atau keberdayaan). Sedangkan, menurut T. Hani Handoko (1997: 33), pemberdayaan adalah suatu usaha jangka panjang untuk memperbaiki proses pemecahan masalah dan melakukan pembaharuan.

Adapun upaya untuk memberdayakan masyarakat, menurut Gunawan (1996: 16), terdiri dari tiga tahapan, sebagai berikut:

1. Menciptakan suasana iklim yang memungkinkan potensi masyarakat untuk berkembang. Pendekatan ini bertitik tolak dari pemahaman bahwa setiap masyarakat memiliki potensi (daya) yang dapat dikembangkan;

2. Memperkuat potensi atau daya yang dimiliki oleh masyarakat, dalam tahapan ini diperlukan langkah-langkah lebih positif dan nyata, serta perembukaan akses kepada berbagai peluang yang akan membuat masyarakat menjadi semakin berdaya dalam memanfaatkan peluang tersebut;

3. Memberdayakan juga mengandung arti menanggulangi kendala-kendala yang 
mampu menghambat masyarakat untuk lebih berdaya.

Dalam pemberdayaan masyarakat, tidak dapat dipungkiri pentingnya peran aktor sebagai community worker. Menurut Peter Salim dalam Kamus Bahasa Indonesia Kontemporer, peran adalah sesuatu yang diharapkan dapat dimiliki oleh aktor sosial yang memiliki kedudukan dalam masyarakat. Karenanya, dalam suatu intervensi komunitas, perlu adanya peran dari community worker sebagai penunjang dalam proses pemberdayaan yang baik. Menurut Zastrow, seperti yang dikutip oleh Isbandi (2001: 62), dijelaskan sedikitnya ada tujuh peran community worker dalam intervensi komunitas. Pertama, pemercepat (Enabler). Sebagai seorang pemercepat, community worker membantu masyarakat untuk memahami dan mengidentifikasi permasalahan yang ada, serta mengembangkan kapasitas mereka agar mampu menangani masalahnya tersebut. Dasar filosofis dari peran ini adalah "help people to help themselves".

Kedua, perantara (broker). Peran perantara dalam pemberdayaan masyarakat ini dilakukan untuk menghubungkan suatu individu, atau kelompok dalam masyarakat yang membutuhkan layanan atau servis, namun mereka tidak tahu harus bagaimana dan kepada siapa dapat meminta bantuan lembaga yang dapat memberikan layanan masyarakat. Misalnya, ketika para peternak Ikan Lele Sangkuriang tidak tahu harus menjual hasil panen ke mana, maka tugas broker adalah membantu mereka untuk memasarkan hasil panen tersebut.

Ketiga, pendidik (edukator). Dalam menjalankan peran pendidik, seorang community worker harus menguasai ilmu yang akan dibagikannya kepada para penerima manfaat agar terhindar dari kesalahan-kesalahan, khususnya yang bersifat teknis. Namun, tidak jarang pula community worker juga meminta bantuan dari profesi lain yang sudah ahli dalam bidang yang akan didiskusikan dengan penerima manfaat.

Keempat, tenaga ahli (expert). Dalam kaitan dengan peran sebagai tenaga ahli, community worker diharapkan dapat memberikan masukan, saran dan dukungna informasi dalam berbagai area. Misalnya, seorang tenaga ahli memberikan usulan mengenai bagaimana struktur organisasi yang bisa dikembangkan dalam suatu organisasi nirlaba yang menangani masalah lingkungan; kelompok mana saja yang harus terwakili atau memberi masukan mengenai isu-isu yang pantas dikembangkan dalam suatu komunitas.

Kelima, perencana sosial (social planner). Seorang perencana sosial mengumpulkan data mengenai masalah sosial yang terdapat dalam komunitas, memetakan, menganalisa dan menyajikan tindakan alternatif secara rasional untuk menangani masalah tersebut. Setelah itu perencana sosial mengembangkan program, mencoba mencari sumber pendanaan alternatif dan mengembangkan konsensus dalam kelompok yang mempunyai berbagai minat maupun kepentingan.

Keenam, advokat (advocate). Peran sebagai advokat dalam community work dicangkok dari dunia hukum. Peran advokat di satu sisi berpijak pada tradisi pembaharuan 
sosial, dan di sisi lainnya berpijak pada tradisi pelayanan sosial. Peran ini melatari tindakan aktif dan terarah, di mana community worker menjalankan fungsi advokasi atau pembelaan dalam mewakili kelompok masyarakat yang membutuhkan bantuan atau layanan, sementara institusi yang seharusnya memberikan bantuan atau pun layanan tidak memedulikan, baik bersifat negatif atau pun menolak tuntutan warga. Dalam menjalankan fungsi advokasi, seorang community worker tidak jarang harus melakukan persuasi terhadap kelompok profesional atau pun kelompok tertentu, agar dapat mencapai tujuan yang diharapkan dalam kaitannya dengan upaya mengembangkan suatu komunitas.

Ketujuh, aktivis (activist). Sebagai aktivis, seorang community worker mencoba melakukan perubahan institusional yang lebih mendasar, dan seringkali tujuannya adalah pengalihan sumber daya atau pun kekuasaan (power) pada kelompok yang kurang mendapatkan keuntungan. Seorang aktivis biasanya memperhatikan isu-isu tertentu, seperti ketidaksesuaian dengan hukum yang berlaku, kesenjangan dan perampasan hak.

\section{Abah Nasrudin sebagai Sosial Worker}

Abah Nasrudin, yang kerap disapa dengan Abah Nas, lahir di Bogor pada tanggal 11 Mei 1948. Kini, usianya sudah genap 66 tahun; usia yang sudah sangat matang dan pantas untuk mendapatkan julukan Abah. Dia tinggal dengan seorang istri dan lima anaknya di Kampung Sukabirus, RT. 004/005, Desa Gadog, Kecamatan Megamendung, Kabupaten Bogor. Saat ini keadaannya serba berkecukupan dan tidak berbanding lurus dengan kehidupannya di masa lampau. Di masa lalu, Abah Nas bukanlah sosok yang dikenal banyak orang; jangankan di luar negeri, di kampungnya sendiri pun Abah Nas masih belum terlalu dikenal. Namun, karena sering bersosialisasi, kemudian mengikuti berbagai pelatihan yang dilakukan oleh pemerintah setempat, akhirnya Abah Nas mulai dikenal banyak orang, meski belum sampai ke seluruh nusantara, yang merupakan awal dari popularitas Abah Nas di seluruh warga Indonesia, bahkan hingga manca negara, terutama di kalangan agribisnis. Sebagai orang yang tidak lulus SR (Sekolah Rakyat), Abah Nas dapat dipandang sangat beruntung jika dilihat dari kehidupannya sekarang ini. Sebagai seorang warga yang tidak mampu membaca, dia mampu menghasilkan pundi-pundi uang yang mampu mencukupi kebutuhan seluruh keluarganya.

Kesuksesan Abah Nasrudin saat ini bukanlah sekedar pemberian Tuhan, namun juga diimbangi dengan usaha yang gigih sebagai orang yang ulet dan bekerja keras. Dalam suatu kesempatan, Abah Nas mengikuti pelatihan budidaya ikan lele yang dilakukan oleh BBPBAT Sukabumi pada tahun 2001. Dari pelatihan tersebut, Abah Nas diberikan mandat oleh BBPBAT untuk membudidayakan Ikan Lele Sangkuriang, yang saat itu masih belum banyak dikenal oleh masyarakat, karena perbedaan jenis serta namanya. Bekal yang diberikan oleh BBPBAT Sukabumi itu pun tidak disia-siakan oleh Abah Nas, sehingga dia mampu mengembangkan budidaya Ikan Lele Sangkuriang, yang merupakan satu jenis ikan 
lele dari hasil perubahan genetik, serta mensosialisasikannya kepada masyarakat secara luas. Kini, Abah Nasrudin memiliki puluhan kolam pembenihan dan pembesaran. Kolamkolam itulah yang menjadi salah satu penyumbang kehidupannya.

Abah Nasrudin mengembangkan metode tersendiri dalam proses pengelolaan budidaya Ikan Lele Sangkuriang, sebagai upaya pemberdayaan masyarakat di Kecamatan Megamendung. Metode tersebut dapat diurai dalam lima tahapan.

Tahapan pertama adalah memberikan pelatihan kepada para penerima manfaat sebagai dasar dalam budidaya Ikan Lele Sangkuriang. Tahapan ini dapat dibagi menjadi dua segmen sebagai berikut:

1. Segmen Pembenihan. Dalam segmen ini, pelatihan dilakukan selama tiga hari berturut-turut, dari hari Jumat pukul 14.00 hingga hari Minggu pukul 10.00. Segmen ini menanggulangi masalah pengangguran secara tidak langsung. Dengan adanya peserta yang mengikuti pelatihan ini, maka mereka akan merekrut masyarakat untuk menjadi karyawan, artinya ada pembukaan lapangan pekerjaan melalui peserta pelatihan terhadap masyarakat umum. Berikut adalah proses pelatihan pada segmen pembenihan:

Tabel 1:

\section{Agenda Pelatihan Pembenihan Ikan Lele Sangkuriang ${ }^{1}$}

\begin{tabular}{|c|c|}
\hline Hari & Waktu dan Kegiatan \\
\hline Jumat & $\begin{array}{l}\text { 1. Pukul 14.00-15.00 : } \\
\text { Pengarahan kepada para peserta pelatihan tentang tahapan } \\
\text { pelatihan } \\
\text { 2. Pukul 15.00-15.30 : } \\
\text { Istirahat dan sholat } \\
\text { 3. Pukul 15.30-16.30 : } \\
\text { Peserta diajak praktek langsung ke kolam untuk } \\
\text { mempersiapkan pemijahan ikan, dari pembersihan kakaban, } \\
\text { yaitu tempat bertelur ikan lele berupa ijuk, pemilihan calon } \\
\text { indukan Ikan Lele Sangkuriang yang siap pijah/kawin, } \\
\text { hingga memasukan calon indukan lele ke kolam pemijahan. } \\
\text { 4. Pukul 16.30-17.00 : } \\
\text { Diskusi tentang teknis pemijahan di kolam pemijahan } \\
\text { secara detail } \\
\text { 5. Pukul 17.00-19.30 : } \\
\text { Ishoma }\end{array}$ \\
\hline
\end{tabular}

1 Observasi pribadi di Farm Lele Sangkuriang milik Abah Nasrudin di Desa Gadog Kecamatan Megamendung pada 13 Juni-25 Juli 2014 


\begin{tabular}{|c|c|}
\hline & $\begin{array}{l}\text { 1. Pukul 08.00-08.15: } \\
\text { Peserta mengobservasi kolam-kolam yang tersedia dan } \\
\text { dilanjutkan dengan praktek langsung melakukan pencucian } \\
\text { kolam penetasan dan pemeliharaan } \\
\text { 2. Pukul 08.15-08.30: } \\
\text { Praktek pembuatan kakaban } \\
\text { 3. Pukul 08.30-08.45: } \\
\text { Praktek pemasangan terpal. } \\
\text { 4. Pukul 08.45-09.00 : } \\
\text { Melakukan pengamatan telur yang sudah menempel di } \\
\text { kakaban } \\
\text { 5. Pukul 09.00-15.30: } \\
\text { Istirahat } \\
\text { 6. Pukul 15.30-16.00: } \\
\text { Praktek pembongkaran kolam pemijahan serta pemindahan } \\
\text { telur oleh peserta dari kolam pemijahan ke kolam penetasan } \\
\text { dan pemeliharaan, dilanjutkan dengan praktek perawatan air } \\
\text { menggunakan herbal } \\
\text { 7. Pukul 16.00-16.15: } \\
\text { Praktek persiapan cacing sutera dan memberikannya kepada } \\
\text { larva lele yang sudah menetas } \\
\text { 8. Pukul 16.15-16.30: } \\
\text { Praktek pengamatan hama larva ikan lele } \\
\text { 9. Pukul 19.30-20.30: } \\
\text { Pemberian teori oleh Abah Nasrudin dari awal persiapan } \\
\text { kolam, pemilihan indukan, pemijahan, pemberian pakan, } \\
\text { perawatan ikan, hingga pemasaran } \\
\end{array}$ \\
\hline Minggu & $\begin{array}{l}\text { 1. Pukul } 07.30-10.00 \text { : } \\
\text { Praktek penyortiran larva, memisahkan antara yang kecil } \\
\text { dan besar. } \\
\text { 2. Pukul } 10.00 \text { : } \\
\text { Penutupan dan pulang }\end{array}$ \\
\hline
\end{tabular}

2. Segmen Pembesaran. Dalam segmen ini, waktu yang digunakan bersifat dinamis, karena tidak ada hari khusus yang dilakukan dalam pemberian pelatihan. Segmen pembesaran juga merupakan segmen yang paling sering digunakan dalam upaya pemberdayaan masyarakat secara langsung, di mana para penerima manfaat akan melakukan langsung budidaya Ikan Lele Sangkuriang, bukan sebagai karyawan. Adapun teori yang diberikan oleh Abah Nasrudin pada tahap awal 
adalah persiapan kolam, pendederan benih, pemberian pakan dan treatment air.

Tahapan kedua adalah memberikan pendampingan dalam bentuk konsultasi budidaya Ikan Lele Sangkuriang, supaya kegiatan budidaya Ikan Lele Sangkuriang dapat memberikan manfaat, berjalan dengan baik dan berhasil. Pendampingan dilakukan secara fleksibel, bisa dilakukan dengan bertemu secara langsung dan berkonsultasi, atau bisa juga berkonsultasi melalui telepon genggam.

Tahapan ketiga adalah memberikan motivasi kepada para penerima manfaat. Pengembangan Ikan Lele Sangkuriangan tidak selalu berjalan lancar, dan sering menemukan berbagai kendala dalam prosesnya, sehingga diperlukan juga motivasi, terutama bagi para pengembang baru, untuk tidak mudah menyerah.

Tahapan keempat adalah memfasilitasi para penerima manfaat dengan jaminan pasar dan memberikan herbal gratis. Salah satu faktor yang mendukung bertahannya pengembangan budidaya Ikan Lele Sangkuriang adalah adanya jaminan untuk memperoleh hasil dari proses yang telah diupayakan. Karenanya, dibutuhkan herbal gratis untuk menjamin kesuksesan peternakan Ikan Lele Sangkuriang, dan tersedianya jaringan untuk memasarkannya.

Tahapan kelima adalah mengevaluasi hasil budidaya Ikan Lele Sangkuriang. Setelah para penerima manfaat memanen hasil budidaya Ikan Lele Sangkuriang, mereka akan menjual hasil panennya kepada Abah Nasrudin. Dari jumlah ikan lele yang dijual kepada Abah Nasrudin, akan terlihat berapa persentase keberhasilan para penerima manfaat. Selain itu, para penerima manfaat akan menceritakan proses budidaya dari awal hingga panen. Jika terjadi beberapa kesalahan teknis, Abah Nasrudin akan langsung memberi masukan kepada para penerima manfaat agar kegagalan yang sebelumnya terjadi dapat diminimalisir.

\section{Kesimpulan}

Terdapat lima peran comminuty worker yang dilakukan oleh Abah Nasrudin dalam upaya penanggulangan pengangguran di Kecamatan Megamendung. Pertama, pemercepat perubahan (Enabler): Abah Nasrudin telah membangkitkan masyarakat untuk mengembangkan usaha mikro, yaitu budidaya Ikan Lele Sangkuriang sebagai alat untuk mengangkat perekonomian masyarakat Kecamatan Megamendung. Abah Nas juga menyediakan fasilitas konsultasi gratis bagi para penerima manfaat, dan bahkan memberikan herbal secara cuma-cuma selama proses pendampingan berlangsung, serta selalu memberikan dorongan dan motivasi sehingga mampu membangkitkan semangat mereka dalam upaya pemberdayaan masyarakat melalui budidaya Ikan Lele Sangkuriang. Kedua, pendidik (edukator): Abah Nasrudin memberikan pelatihan kepada para penerima manfaat sebagai dasar atau acuan bagi para penerima manfaat dalam budidaya ikan Lele Sangkuriang. Ketiga, tenaga ahli (expert): Abah Nasrudin mensosiaslisasikan dan memberi informasi kepada masyarakat terkait dengan usahanya melakukan penanggulangan 
pengangguran di Kecamatan Megamendung melalui budidaya Ikan Lele Sangkuriang. Selain itu, dia selalu memberikan saran serta masukan kepada para petani binaannya setelah memanen ikan lele hasil budidayanya. Keempat, perencana sosial (social planner): Abah Nasrudin mengadakan program pemberdayaan masyarakat melalui budidaya ikan Lele Sangkuriang, baik yang bersifat individu maupun kelompok tani. Kelima, perantara (broker): Abah Nasrudin menyambungkan pihak luar agar memberikan donasi kepada kelompok tani binaannya serta membantu para petani binaannya untuk memasarkan hasil panen mereka. 


\section{Bibliografi}

Adi, Isbandi Rukminto, Intervensi Komunitas Pengembangan Masyarakat sebagai Upaya Pemberdayaan Masyarakat. Jakarta : Rajawali Press, 2008. , Pemberdayaan Pengembangan Masyarakat Dan Intervensi Komunitas. Jakarta: Fakultas ekonomi Universitas Indonesaia, 2001.

Adiburijal, Permberdayaan Eks Wanita Tuna Sussila melalui Pelatihan Keterampilan Tata Rias Pengantin di Panti Sosial Karya Wanita "Mulya Jaya". Jakarta: Jurusan Pengembangan Masyarakat Islam FDIK, 2011.

Alma, Buchari, Kewirausahaan. Bandung: Alfabeta, 2011.

Bungin, M. Burhan, Penelitian Kualitatif. Jakarta: Kencana Prenada Media Group, 2007.

Et al, Geoffrey G Meredith, Kewirausahaan: Teori dan Praktek. Jakarta: PT. Pustaka Binaman Pressindo, 1995.

Huraerah, Abu, Pengorganisasian dan Pengembangan Masyarakat. Bandung: Humaiora, 2011.

Irwanto, Focused Group Discussion. Jakarta: Yayasan Obor Indonesia, 2006.

Kasmir, Kewirausahaan. Jakarta: PT. Raja Grafindo Persada, 2013.

Kriyantono, Rachmat, Teknik Praktis Riset Komunikasi. Jakarta: Kencana Prenada Media Group, 2009.

Mardalis, Metode Penelitian Suatu Pendekatan Proposal. Jakarta: Bumi Aksara, 2003.

Muhtadi dan Tantan Hermansah, Manajemen Pengembangan Masyarakat Islam. Jakarta: UIN Jakarta Press, 2013.

Nasrudin, Jurus Sukses Beternak Lele Sangkuriang. Jakarta: PT. Agro Media Pustaka, 2010.

Pramuwito, Pengantar Ilmu Kesejahteraan Sosial. Yogyakarta: Departmen Sosial RI Badan Penelitian dan Pengembangan Kesejahteraan Sosial, 1996.

Prasetyo, Bambang dan Lina Miftahul Janah. Metode Penelitian Kuantitatif: Teori dan Aplikasinya. Jakarta: PT Raja Grafindo Persada, 2006.

Pratama, Bagus Adhi, Pemberdayaan Masyarakat melalui Kegiatan Daur Ulang Sampah di Perumahan Griya Serpong Kademangan Setu Tangerang Selatan Banten. Jakarta: Jurusan Pengembangan Masyarakat Islam FDIK, 2012.

Puniman, FX., Nasrudin Bapak Lele Sangkuriang. Bogor: Kompas, edisi Senin 21 Desember 2009.

Rasyid, Sudrajat, dkk., Kewirausahaan Santri (Bimbingan Santri Mandiri). Jakarta: Citrayuda, 2005.

Salam, Syamsir dan Amir Fadhilah, Sosiologi Pedesaan. Jakarta: Lembaga penelitian UIN Syarif Hidayatullah Jakarta, 2008.

Siagian, Salim dan Asfahani, Kewirausahaan Indonesia dengan Semangat 17-8-45. Jakarta: Kloand KLede Jaya dan Departemen Koperasi dan Pembinaan Pengusaha Kecil, 
1995.

Suharto, Edi, Membangun Masyarakat Memberdayakan Rakyat. Bandung: PT Refika Aditama, 2005.

Suherman, Eman, Desain Pembelajaran Kewirausahaan. Bandung: Alfabeta, 2010.

Sumodiningrat, Gunawan, Pemberdayaan Masyarakat dan Jaring Pengaman Sosial. Jakarta: PT. Gramedia Pustaka Utama, 1999.

Sumodiningrat, Gunawan, Pengembangan Daerah dan Pemberdayaan Masyarakat. Jakarta: PT. Bina Rena Pariwara, 1996.

Usman, Husaini dan Purnomo Setiadi Akbar, Metodologi Penelitian Sosial. Jakarta: Bumi Aksara, 1998.

Wibowo, Kesit Tisna, Mendongkrak Produksi Lele dengan Sistem Padat Tebar Tinggi. Jakarta: PT. Agromedia Pustaka, 2012.

Yulistiani, Indriati, Ragam Penelitian Kualitatif: Penelitian Lapangan. Jakarta: FISIP UI, 2001. 